Article

\title{
Pineapple Waste Cell Wall Sugar Fermentation by Saccharomyces cerevisiae for Second Generation Bioethanol Production
}

\author{
Fabio Salafia ${ }^{1}$ (D), Antonio Ferracane ${ }^{2, *(D)}$ and Alessia Tropea ${ }^{3, *}$
}

1 Food Chemistry, Safety and Sensoromic Laboratory (FoCuSS Lab), Department of Agriculture, University "Mediterranea" of Reggio Calabria, Via dell’Università, 25, 89124 Reggio Calabria, Italy; fabio.salafia@unirc.it

2 Department of Chemical, Biological, Pharmaceutical and Environmental Sciences, University of Messina, Polo Annunziata, Viale Annunziata, 98166 Messina, Italy

3 Department of Research and Internationalization, University of Messina, Via Consolato del Mare, 41, 98100 Messina, Italy

* Correspondence: aferracane@unime.it (A.F.); atropea@unime.it (A.T.)

check for updates

Citation: Salafia, F.; Ferracane, A.; Tropea, A. Pineapple Waste Cell Wall Sugar Fermentation by Saccharomyces cerevisiae for Second Generation Bioethanol Production. Fermentation 2022, 8, 100. https://doi.org/ $10.3390 /$ fermentation 8030100

Academic Editor: Gunnar Lidén

Received: 11 February 2022 Accepted: 25 February 2022 Published: 27 February 2022

Publisher's Note: MDPI stays neutral with regard to jurisdictional claims in published maps and institutional affiliations.

Copyright: (c) 2022 by the authors. Licensee MDPI, Basel, Switzerland. This article is an open access article distributed under the terms and conditions of the Creative Commons Attribution (CC BY) license (https:// creativecommons.org/licenses/by/ $4.0 /)$.

\begin{abstract}
Agricultural food waste is rich in cellulosic and non-cellulosic fermentable substance. In this study, we investigated the bioconversion of pineapple waste cell wall sugars into bioethanol by simultaneous saccharification and fermentation using Saccharomyces cerevisiae ATCC 4126. Soluble and insoluble cell wall sugars were investigated during the fermentation process. Moreover, the fermentation medium was investigated for protein, moisture, ash, lignin and glycerol determinations with a particular focus on the increase in single cell protein due to yeast growth, allowing a total valorization of the resulting fermentation medium, with no further waste production, with respect to environmental sustainability. Soluble and insoluble sugars in the starting material were $32.12 \%$ and $26.33 \%$ respectively. The main insoluble sugars resulting from the cell wall hydrolysis detected at the beginning of the fermentation, were glucose, xylose and uronic acid. Glucose and mannose were the most prevalent sugars in the soluble sugars fraction. The ethanol theoretical yield, calculated according to dry matter lost, reached up to $85 \%$ (3.9\% EtOH). The final fermentation substrate was mainly represented by pentose sugars. The protein content increased from $4.45 \%$ up to $20.1 \%$ during the process.
\end{abstract}

Keywords: ethanol; simultaneous saccharification and fermentation; Saccharomyces cerevisiae; single cell protein; food waste; pineapple waste; cell wall sugar; fermentation

\section{Introduction}

Waste disposal is one of the major problems facing most food processing plants [1,2]. According to Campos et al. [3], there is an increasing interest in the valorization of the wastes generated by the food industry, including waste generated as a consequence of the new developments in process engineering and the resulting byproducts [4].

Waste utilization in the fruit and vegetable processing industry is an important challenge that governments must address in order to promote sustainability $[3,5]$. Additionally, these substrates have a high potential, due to their micro and macro composition [6,7], as a low-cost high-potency second-generation feed-stock that can easily undergo biodegradation [8].

Among agricultural food waste, pineapple industrialization is known to generate a significant amount of solid residues, and values between $75-80 \%$ have been reported [5,9]. In the past, pineapple wastes were utilized as sources for bromelain extraction, wine and vinegar production, yeast cultivation for food/feed proteins, or also for organic acid production. They can also be a source for other bioactive compounds, such as antioxidants [10-14].

Pineapple wastes, such as the fruit peel and crown, are comprised of lignin, hemicellulose and cellulose. For this reason, they are considered to be lignocellulosic materials that 
can be used in the production of second-generation bioethanol, after pre-treatment and hydrolysis, in order to provide fermentable sugars for the subsequent fermentation $[15,16]$.

Hydrolyzation is the main step for lignocellulosic biomass fermentation; in fact, the polysaccharides are tightly packed in plant cell walls and are often surrounded by lignin, forming highly recalcitrant structures resistant to direct enzymatic attack $[17,18]$. Enzymatic hydrolysis is regarded today as the most promising approach for liberating fermentable sugars in an energy-efficient way from the carbohydrates found in lignocelluloses in order to produce bioethanol via fermentation $[19,20]$.

According to Pereira et al. [21], among the different microbes used for bioethanol production, the yeast Saccharomyces cerevisiae is the most commonly used organism because of its good fermentative capacity, high tolerance to ethanol and other inhibitors (either formed during raw material pre-treatments or produced during fermentation), and its capacity to grow rapidly under anaerobic conditions, as are typically established in largescale vessels [22].

Ethanol production is mainly dependent on glucose concentration (the theoretical alcohol yield is about $0.5 \mathrm{~g}$ of ethanol per $\mathrm{g}$ of glucose), but nutrient supplementation is also an important parameter to take into consideration, since an adequate amount of specific nutrients, such as trace elements, vitamins and nitrogen, often poor in agricultural waste, can significantly improve yeast viability and resistance to the medium, stimulating ethanol production performances $[15,23]$.

Several related studies about bioethanol production from pineapple wastes report different fermentation approaches, such as direct fermentation (DF), separate hydrolysis and fermentation (SHF) and simultaneous saccharification and fermentation (SSF) [24-26]. Among these fermentation processes, SSF has the advantage of preventing the buildup of hydrolysis, such as cellobiose and glucose, which can reduce the rate of further substrate hydrolysis. However, it has to be carried out at temperatures that suit the fermenting organism. In the case of yeast, the temperature is generally below $40{ }^{\circ} \mathrm{C}$, which is below the optimum temperature for enzymatic hydrolysis $\left(50^{\circ} \mathrm{C}\right)$ [27].

The present research is focused on the evaluation of pineapple waste cell wall sugars as an alternative source of second-generation bioethanol. This study utilizes Saccharomyces cerevisiae ATCC 4126 to carry out an SSF process using a supplemented medium, by the addition of a specific nitrogen source, salts, and vitamins, which are required by the yeast in order to improve its ability to use the substrate both for alcohol production and for its own growth. The high amount of cell wall sugars in pineapple waste prompted us to utilize it as a raw material for bioethanol production and as a cheap medium. Moreover, the initial and final fermentation mediums were investigated with a particular focus on the increase of single cell protein due to yeast growth, making the resulting fermented substrate suitable as animal feed. This allows a total valorization of the resulting fermentation medium, with no further waste production, with respect to environmental sustainability.

\section{Materials and Methods}

\subsection{Substrate}

Pineapples were purchased from a local market in Messina, IT. The pineapples were manually cleaned by removing the crown and the pulp. For analytical purposes only, the waste represented by pineapple peel and core (the inner part) have been used as a fermentative substrate. Wastes were cut into small pieces and homogenized in a fruit blender for $5 \mathrm{~min}$.

\subsection{Microorganism}

Saccharomyces cerevisiae ATCC 4126 was maintained on yeast medium (YM) agar (yeast extract $3 \mathrm{~g} / \mathrm{L}$, malt extract $3 \mathrm{~g} / \mathrm{L}$, peptone $5 \mathrm{~g} / \mathrm{L}$, glucose $10 \mathrm{~g} / \mathrm{L}$, agar $20 \mathrm{~g} / \mathrm{L}$, Oxoid, Basingstoke, UK) at $4{ }^{\circ} \mathrm{C}$. To carry out the tests, $S$. cerevisiae was cultured overnight at $30{ }^{\circ} \mathrm{C}$ on a rotary shaker (INNOVA 44, Incubator Shaker Series, New Brunswick Scientific, Edison, NJ, USA) at $250 \mathrm{rpm}$, in $20 \mathrm{~mL}$ YM medium tubes [28]. 
After overnight incubation, the cell suspensions were aseptically harvested by centrifugation (3000 rpm, $5 \mathrm{~min}$, Centrifuge 5810 R, Eppendorf UK Ltd., Stevenage, UK), the supernatant (YM media) was discarded, and the yeast cells were washed twice in $5 \mathrm{~mL} 0.9 \%$ $(w / v) \mathrm{NaCl}$ to minimize nutrient transfer from seed culture to fermentation medium [28].

The total viable yeast cells were measured by using a cell count reader (Nucleocounter ${ }^{\circledR}$ YC $100^{\mathrm{TM}}$, Chemo Metec, Allerød, Denmark). The standard yeast culture contained $10^{8}$ cells per mL of S. cerevisiae ATCC 4126 [28].

\subsection{Experimental Setup}

Fermentation tests were carried out in a $5 \mathrm{~L}$ batch fermenter (Biostat Biotech B, Sartorius Stedim Biotech, Goettingen, Germany). The fermenter was equipped with one four-bladed Rushton turbine and the usual control systems as follows: temperature, $\mathrm{pH}$, $\mathrm{pO}_{2}, \mathrm{pCO}_{2}$ and a foam detector.

Pineapple waste, comprising fruit skin and core, were homogenized in a fruit blender for $5 \mathrm{~min}$. The resulting homogenate, with a dry matter content of $14 \%(w / w)$, was diluted with water to a $9 \%$ dry matter, in a working volume of $3.5 \mathrm{~L}$ and immediately treated at $100{ }^{\circ} \mathrm{C}$ for $10 \mathrm{~min}$ under continuous mixing to inactivate endogenous enzymes and reduce microbial spoilage. No further sterilization procedures were adopted [4].

SSF fermentation was carried out by adding a $2 \%(v / v)$ inoculum of $S$. cerevisiae $\left(10^{8}\right.$ cells per $\left.\mathrm{mL}\right)$ and the enzymes $\left(20 \mu \mathrm{L} / \mathrm{g}\right.$ dry matter of Depol ${ }^{\mathrm{TM}} 740 \mathrm{~L}$ and $250 \mu \mathrm{L} / \mathrm{g}$ dry matter of Accellerase ${ }^{\circledR} 1500$ enzymes) to the substrate. Both of the enzymes were added to the medium according to Tropea et al. [25].

According to Tropea et al. [23], the fermentation medium was supplemented with urea phosphate salt $2.3 \mathrm{~g} / \mathrm{L}, \mathrm{KCl} 0.2 \mathrm{~g} / \mathrm{L}, \mathrm{MgSO}_{4} \cdot 7 \mathrm{H}_{2} \mathrm{O} 3.8 \mathrm{~g} / \mathrm{L}$, Ca-pantothenate $0.0833 \mathrm{mg} / \mathrm{L}$ and biotin $0.0833 \mathrm{mg} / \mathrm{L}$.

Fermentation parameters were $30{ }^{\circ} \mathrm{C}, \mathrm{pH} 5$ and constant stirring at $200 \mathrm{rpm}$. The $\mathrm{pH}$ value was previously adjusted from 3.8 up to 5 , using $2 \mathrm{M} \mathrm{NaOH}$.

$\mathrm{CO}_{2}$ evolution was measured during all fermentation tests using a BioPAT ${ }^{\circledR}$ Xgas 1 analyser for BIOSTAT ${ }^{\circledR}$ B-DCU II system (Sartorius Stedim Biotech, Goettingen, Germany) and duplicate broth samples were withdrawn from the reaction vessel using a $20 \mathrm{~mL}$ syringe. Samples for ethanol analysis were immediately frozen at $-18{ }^{\circ} \mathrm{C}$ until analysis, whereas samples for the other determinations were heated at $100{ }^{\circ} \mathrm{C}$ for $10 \mathrm{~min}$, to inactivate the enzymes and stop any further fermentation, and then frozen at $-18^{\circ} \mathrm{C}$ until analyzed. All fermentations were carried out until no further $\mathrm{CO}_{2}$ fluctuations were observed. The $\mathrm{pH}$ was not controlled by the addition of an alkali during fermentation [4].

\subsection{Chemicals}

Chemicals were purchased from Sigma Aldrich (Bellefonte, PA, USA), except for galacturonic acid and glucose, which were purchased from Fluka Biochemical (Buchs, Switzerland); glycerol, $\mathrm{KCl}, \mathrm{MgSO}_{4} \cdot 7 \mathrm{H}_{2} \mathrm{O}$, and Ca-pantothenate, which were provided by Fisher Scientific (UK Ltd., Loughborough, UK); and biotin, which was provided by Calbiochem.

Commercially available enzyme solutions DepolTM 740 L (ferulic acid esterase), provided by Biocatalysts Ltd., Cefn Coed, Wales, U.K and Accellerase ${ }^{\circledR} 1500$ (endoglucanase), provided by Genencor (Rochester, NY, USA), were used.

\subsection{Protein, Moisture, Ash and Lignin Determinations}

Representative samples were drained off for protein content testing using the method suggested by the AOAC [29]. The protein percentage was calculated considering a conversion factor of 6.25. The increase in protein was quantified by the Büchi Kjeldahal (Büchi, Switzerland) instrument, equipped with the Büchi Distillation Unit B-324 (Büchi, Switzerland), Digestion Unit K-424 and Scrubber B-414 (Büchi, Switzerland), used for crude protein determination as total $\mathrm{N}$, multiplying the results by the conversion factor. 
The dry weights were calculated as steady weights after $2 \mathrm{~h}$ at $110^{\circ} \mathrm{C}$ using a Mettler PM 200 equipped with a Mettler LP16 IR balance (Mettler-Toledo GmbH, Laboratory \& Weighing Technologies, Greifensee, Switzerland).

Ash determination was carried out according to the AOAC method [29]. Klason lignin was quantified gravimetrically according to Carrier et al. [30]. All samples were analyzed in triplicate.

\subsection{Alcohol-Insoluble Residues (AIR)}

AIR samples were prepared prior to analysis for cell wall sugars. Wet fermented pineapple waste samples, after defrosting, were homogenized for $1 \mathrm{~min}$ at maximum speed in a Janke \& Kunnel, Ika-Werk Ultra-Turrax homogenizer at room temperature and then poured into boiling ethanol for obtaining a final mixture that had an $\mathrm{EtOH}$ concentration of $85 \%(v / v)$. Sample particles from the homogenizer were collected using $50 \mathrm{~mL}$ of $70 \%$ $\mathrm{EtOH}$. The insoluble residue was recovered by vacuum filtration using a $5 \mu \mathrm{m}$ nylon filter NYBOLT by a Buchner funnel. After two further sequential extractions in boiling $85 \%$ ethanol $(v / v)$ the residue was extracted in boiling absolute ethanol and then washed with cold absolute ethanol. The final filtrate was dried by a rotating evaporator (Büchi, Switzerland) at $40{ }^{\circ} \mathrm{C}$, recovered in water and tested for residual soluble sugars. The insoluble residue was washed with two volumes of acetone and after removal by suction, dried to a constant weight at $40{ }^{\circ} \mathrm{C}[31,32]$ and analyzed for insoluble sugars determination.

\subsection{Sugar Analysis}

Insoluble sugars were released from AIR samples by hydrolysis and analyzed by gas chromatography-flame ionization detection (GC-FID) after conversion to their alditol acetates. As an internal standard, 2-deoxyglucose was used [33]. Monosaccharides were released from polysaccharides with pre-hydrolysis of the samples using $0.2 \mathrm{~mL}$ of $72 \%(w / w)$ $\mathrm{H}_{2} \mathrm{SO}_{4}$ for $3 \mathrm{~h}$ at room temperature, followed by $2.5 \mathrm{~h}$ of hydrolysis in $1 \mathrm{M} \mathrm{H}_{2} \mathrm{SO}_{4}$ at $100{ }^{\circ} \mathrm{C}$. A total of $0.5 \mathrm{~mL}$ was collected for uronic acid determination after $1 \mathrm{~h}$ of hydrolysis. Hydrolysis was followed by the reduction and acetylation of the monosaccharides, and the alditol acetates were analyzed by Shimadzu Gas Chromatograph GC-2010, equipped with a Flame Ionization Detector (GC/FID) (Kyoto, Japan), by using a capillary column DB-225 (30 m length, $0.25 \mathrm{~mm}$ ID and $0.15 \mu \mathrm{m} \mathrm{d}_{f}$ (50\%-Cyanopropylphenyl)-dimethylpolysiloxane) [34].

The same protocol, starting from hydrolysis in $1 \mathrm{M} \mathrm{H}_{2} \mathrm{SO}_{4}$, was carried out for the determination of the residual soluble sugar in the supernatant fraction. The oven temperature program was as follows: $200{ }^{\circ} \mathrm{C}$ to $220^{\circ} \mathrm{C}$ at a rate of $40{ }^{\circ} \mathrm{C} / \mathrm{min}(7 \mathrm{~min})$, increasing to $230{ }^{\circ} \mathrm{C}$ at a rate of $20^{\circ} \mathrm{C} / \mathrm{min}(1 \mathrm{~min})$. The temperature of the injector was $220^{\circ} \mathrm{C}$ and the detector was $230^{\circ} \mathrm{C}$. The carrier gas used was hydrogen, at a flow rate of $1.7 \mathrm{~mL} / \mathrm{min}$. The free sugars were identified and quantified based on their retention times, and response factors obtained by the injection of standards. Uronic acid content was determined by the m-phenylphenol colorimetric method [35], modified according to Rae et al. [36], and the galacturonic acid was used as the standard. To the $0.5 \mathrm{~mL}$ of diluted hydrolyzed sample (1:4), $3 \mathrm{~mL}$ of boric acid $50 \mathrm{mM} \mathrm{H}_{2} \mathrm{SO}_{4} 98 \%(w / w)$ was added. After shaking, the test tubes were heated at $100{ }^{\circ} \mathrm{C}$ for $10 \mathrm{~min}$. A quantity of $100 \mu \mathrm{L}$ of m-phenylphenol was added after cooling, reacting for $30 \mathrm{~min}$ in the dark, and the absorbance was measured at $520 \mathrm{~nm}$. All samples were analyzed in triplicate.

\subsection{Alcohols Determination}

Ethanol and glycerol were quantified by HPLC. A total of $500 \mu \mathrm{L}$ of supernatant sample from fermented pineapple waste were centrifuged for $10 \mathrm{~min}$ at $500 \mathrm{rpm}$ and $20^{\circ} \mathrm{C}$ in a 96-deep well plate using an Eppendorf Centrifuge $5810 \mathrm{R}$, then filtered through AcroPrep $^{\mathrm{TM}} 0.2 \mu \mathrm{m}$ GHP Membrane 96-Well Filter Plates into a 96-deep well collection plate for a further $10 \mathrm{~min}$ at the same speed. After centrifugation, plates were covered by a rubber lid and loaded directly onto a Shimadzu HPLC system (Kyoto, Japan), equipped with an autosampler SIL-20A HT, a degasser DGU-20A3, a pump LC-20AD, a column 
oven CTO-20A and a Refractive Index Detector model: RID-10A. Analyses were carried out using an Aminex HPX-87P $300 \times 7.8 \mathrm{~mm}$ carbohydrate analysis column (Bio-Rad Laboratories Ltd., Hemel Hempstead, UK. Resin ionic form: lead. Support: sulfonated divinyl benzene-styrene copolymer. Particle size: $9 \mu \mathrm{m}$.) with matching guard columns (BIO-RAD, MicroGuard ${ }^{\circledR}$ Carbo-P, Hercules, CA, USA), operating at $65{ }^{\circ} \mathrm{C}$ with ultrapure water at a flow rate of $0.6 \mathrm{~mL} / \mathrm{min}$ as the mobile phase, in isocratic mode. The sample injection volume was $20 \mu \mathrm{L}$. Two injections were performed for each sample. Standard curves of anhydrous sugars were produced and myo-inositol (cyclohexane-1,2,3,4,5,6-hexol) was used as the internal standard. The total analysis time was $42 \mathrm{~min}$. All samples were analyzed in triplicate [37].

\section{Results and Discussion}

\subsection{Protein, Moisture, Ash and Lignin}

As shown in Figure 1, protein increased following the same trend observed for ethanol and glycerol production, increasing from an initial $4.45 \%$ to $7.3 \%$ at $t=9$, and reaching the highest concentration (21.3\%) at $t=21$. According to Aruna et al. [38] and Aruna [39], this trend can be ascribed to the yeast cell growth, which can be also referred as single cells proteins (SCP). Moreover, the protein percentage reached in the present study is in line with previous findings, making the final fermented substrate suitable as animal feed. The last fermentation phase was characterized by a 1.2\% protein decrease (Figure 1), due, of course, to the natural yeast cell autolysis during the decline phase of the growth curve $[40,41]$.

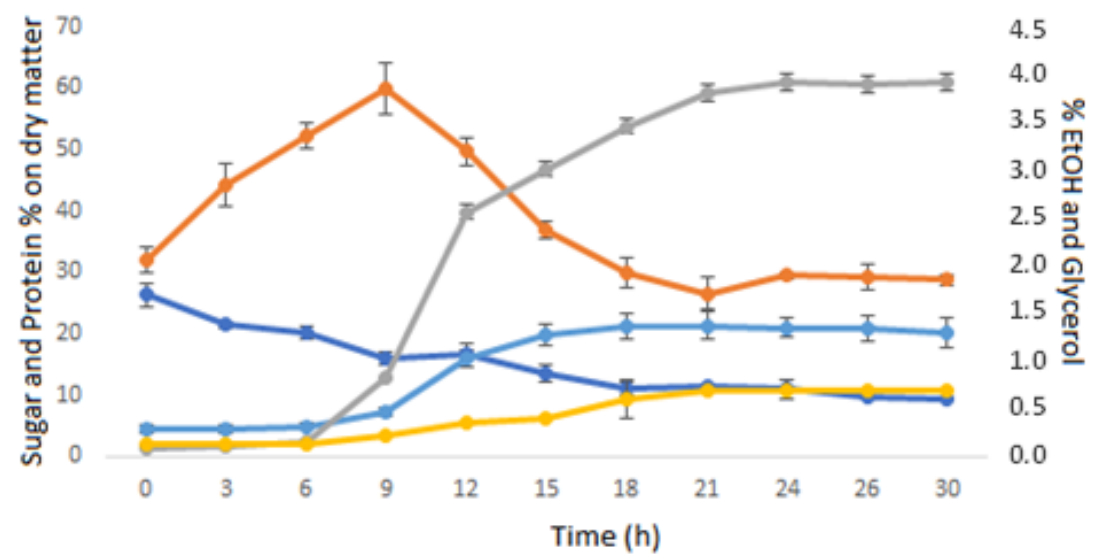

Figure 1. Trend of the main parameters evaluated during the SSF process. Light blue: \% of protein, blue: \% of insoluble sugars, orange: \% of soluble sugars, grey: \% EtOH, yellow: \% of glycerol.

During the SSF processes, the dry matter dropped down from 9\% to $2.5 \%$, leaving around $30 \%$ of the dry matter in the substrate unused. This could be ascribed to the $\mathrm{pH}$ falling during the fermentation period. In fact, the $\mathrm{pH}$ value dropped down from $5.0 \pm 0.3$ to $3.3 \pm 0.2$. The $\mathrm{pH}$ drop was probably caused both by yeast catabolite production and D-galacturonic acid release from pectin [42]. The observed $\mathrm{pH}$ decrease could hamper the enzymatic activity with a consequent arrest of fiber saccharification.

Lignin and ash, whose percentages are shown in Table 1, were $3.89 \%$ and $0.56 \%$, respectively, in the starting material. Whereas, at the end of the fermentation process, the percentages detected in the fermented material were $6.54 \%$ and $0.58 \%$, respectively. The increase in lignin can be explained by remembering that lignin is not involved in alcoholic fermentation [43], and so, according to the literature, the increase in lignin dry matter is typically due to enzymatic fiber hydrolysis [44]. 
Table 1. Fermentation medium composition ${ }^{\text {a }}$

\begin{tabular}{ccc}
\hline & Starting Material & Fermented Material \\
\hline Soluble sugar & $32.12 \pm 2.05$ & $28.7 \pm 0.80$ \\
Insoluble sugar & $26.33 \pm 1.83$ & $9.36 \pm 0.39$ \\
Protein & $4.45 \pm 0.6$ & $20.1 \pm 2.5$ \\
Lignin & $3.89 \pm 0.3$ & $6.54 \pm 0.1$ \\
Ash & $0.56 \pm 0.01$ & $0.58 \pm 0.01$ \\
Dry matter & $9 \pm 0.5$ & $2.5 \pm 0.4$ \\
\hline
\end{tabular}

a Composition reported as percentage of dry matter. Results are means \pm Standard Deviation of triplicate analyses.

The ash percentage was stable around $0.6 \%$ during the whole process. A previous study, where there was no supplementation with minerals and vitamins to the medium, reported an ash percentage decrease, due to a partial ash utilization by the yeast as a source of minerals [45]. In this study, according to Tropea et al. [23], the supplementation with salts and vitamins was followed by a minor ash utilization by the yeast.

\subsection{Cell Wall Insoluble and Soluble Sugars}

Initial soluble and insoluble sugars in pineapple waste processed by SSF were $32.12 \%$ and $26.33 \%$, respectively (Table 1 ).

Table 2 shows the percentage of the insoluble monosaccharides detected during the whole fermentation process. The main sugars resulting from the cell wall hydrolysis of AIR pineapple waste residues detected at the beginning of the fermentation, were $9.84 \%$ glucose (Glc), $8.16 \%$ xylose (Xyl) and $3.18 \%$ uronic acid (UA), followed by $2.46 \%$ arabinose (Ara) and $1.58 \%$ galactose (Gal), with smaller amounts of mannose (Man), rhamnose (Rha) and fucose (Fuc).

Table 2. Cell wall insoluble monosaccharide composition ${ }^{\mathrm{a}}$.

\begin{tabular}{|c|c|c|c|c|c|c|c|c|c|c|}
\hline Hours & Residue & Totals & Rhamnose & Fucose & Arabinose & Xylose & Mannose & Galactose & Glucose & UA \\
\hline 0 & 3.7 & $26.33 \pm 1.83$ & $0.06 \pm 0.01$ & $0.06 \pm 0.01$ & $2.46 \pm 0.18$ & $8.16 \pm 0.64$ & $0.99 \pm 0.02$ & $1.58 \pm 0.12$ & $9.84 \pm 1.07$ & $3.18 \pm 0.17$ \\
\hline 3 & 2.5 & $21.43 \pm 0.62$ & $0.07 \pm 0.01$ & $0.03 \pm 0.01$ & $1.88 \pm 0.07$ & $7.63 \pm 0.66$ & $0.68 \pm 0.05$ & $1.51 \pm 0.15$ & $7.30 \pm 1.14$ & $2.33 \pm 0.14$ \\
\hline 6 & 1.9 & $20.25 \pm 1.11$ & $0.07 \pm 0.01$ & $0.03 \pm 0.01$ & $2.21 \pm 0.20$ & $6.48 \pm 0.76$ & $0.59 \pm 0.08$ & $1.29 \pm 0.07$ & $6.71 \pm 0.71$ & $2.85 \pm 0.25$ \\
\hline 9 & 1.5 & $16.04 \pm 0.95$ & $0.04 \pm 0.01$ & $0.02 \pm 0.01$ & $1.19 \pm 0.02$ & $6.59 \pm 1.42$ & $0.35 \pm 0.03$ & $0.74 \pm 0.07$ & $5.98 \pm 0.85$ & $1.12 \pm 0.36$ \\
\hline 12 & 1.4 & $16.58 \pm 1.89$ & $0.04 \pm 0.01$ & $0.03 \pm 0.01$ & $1.49 \pm 0.19$ & $6.71 \pm 1.94$ & $0.39 \pm 0.02$ & $0.80 \pm 0.14$ & $6.00 \pm 0.23$ & $1.13 \pm 0.33$ \\
\hline 15 & 1.3 & $13.48 \pm 1.50$ & $0.04 \pm 0.01$ & $0.02 \pm 0.0$ & $1.25 \pm 0.11$ & $5.45 \pm 1.11$ & $0.39 \pm 0.01$ & $0.69 \pm 0.04$ & $4.80 \pm 0.57$ & $0.82 \pm 0.03$ \\
\hline 18 & 1.0 & $11.13 \pm 1.08$ & $0.03 \pm 0.0$ & $0.02 \pm 0.0$ & $0.69 \pm 0.09$ & $5.00 \pm 0.68$ & $0.48 \pm 0.01$ & $0.55 \pm 0.02$ & $3.43 \pm 0.42$ & $0.94 \pm 0.10$ \\
\hline 21 & 0.9 & $11.41 \pm 0.27$ & $0.03 \pm 0.0$ & $0.02 \pm 0.0$ & $0.89 \pm 0.02$ & $4.45 \pm 0.47$ & $0.55 \pm 0.03$ & $0.52 \pm 0.04$ & $3.73 \pm 0.25$ & $1.22 \pm 0.41$ \\
\hline 24 & 0.8 & $11.00 \pm 1.60$ & $0.03 \pm 0.01$ & $0.01 \pm 0.0$ & $1.25 \pm 0.08$ & $3.91 \pm 0.94$ & $0.52 \pm 0.01$ & $0.61 \pm 0.07$ & $3.47 \pm 0.33$ & $1.19 \pm 0.21$ \\
\hline 26 & 0.8 & $9.51 \pm 0.17$ & $0.04 \pm 0.01$ & $0.02 \pm 0.01$ & $1.09 \pm 0.09$ & $3.23 \pm 0.58$ & $0.58 \pm 0.01$ & $0.67 \pm 0.12$ & $2.83 \pm 0.39$ & $1.05 \pm 0.09$ \\
\hline 30 & 0.8 & $9.36 \pm 0.39$ & $0.04 \pm 0.01$ & $0.02 \pm 0.0$ & $0.99 \pm 0.10$ & $3.19 \pm 0.72$ & $0.57 \pm 0.02$ & $0.66 \pm 0.11$ & $2.80 \pm 0.29$ & $1.09 \pm 0.15$ \\
\hline
\end{tabular}

${ }^{a}$ Expressed as percentage of insoluble sugar on dry matter calculated in AIR mass basis. Results are shown as means of triplicate analysis \pm Standard Deviation; residue $(\%)=$ proportion of biomass recovered as alcohol insoluble residue (AIR); $\mathrm{UA}=$ uronic acid

In Table 3, the sugars in the soluble fraction detected in alcohol-soluble residue samples (ASR) are reported. The main sugars detected at the beginning of the SSF process were represented by Glc and Man, reaching up to a percentage of $26.33 \%$ and $4.36 \%$, respectively. This starting material sugar composition was in accordance with the results obtained by Abdullah and Mat [9] and Huang et al. [46].

Figure 1 shows the time course of ethanol production and the corresponding levels of soluble and fiber-bound sugars. As it can be observed, the substrate was hydrolyzed in the early phases of the process, as a consequence of the enzyme addition. In fact, a decrease in the insoluble fraction was recorded by $t=3$ in contraposition with an increase in the concentration in soluble sugar.

In all the samples of digested materials, the insoluble sugar decrease was followed by an increase in the concentration of soluble Glc, Man, Xyl, Ara and UA. 
Table 3. Cell wall soluble monosaccharide composition ${ }^{\mathrm{a}}$.

\begin{tabular}{|c|c|c|c|c|c|c|c|c|c|}
\hline Hours & Totals & Rhamnose & Fucose & Arabinose & Xylose & Mannose & Galactose & Glucose & UA \\
\hline 0 & $32.12 \pm 2.05$ & $0.01 \pm 0.00$ & $0.01 \pm 0.00$ & $0.04 \pm 0.01$ & $0.03 \pm 0.01$ & $4.36 \pm 0.24$ & $0.19 \pm 0.00$ & $26.63 \pm 1.80$ & $0.84 \pm 0.03$ \\
\hline 3 & $44.05 \pm 3.48$ & $0.01 \pm 0.01$ & $0.01 \pm 0.00$ & $0.57 \pm 0.02$ & $1.96 \pm 0.08$ & $5.61 \pm 0.18$ & $0.40 \pm 0.02$ & $34.06 \pm 3.06$ & $1.43 \pm 0.31$ \\
\hline 6 & $52.39 \pm 2.10$ & $0.01 \pm 0.00$ & $0.03 \pm 0.00$ & $1.46 \pm 0.08$ & $5.57 \pm 0.52$ & $4.35 \pm 0.48$ & $0.77 \pm 0.08$ & $37.07 \pm 2.14$ & $3.13 \pm 0.41$ \\
\hline 9 & $59.94 \pm 4.05$ & $0.02 \pm 0.00$ & $0.04 \pm 0.01$ & $2.22 \pm 0.25$ & $9.15 \pm 0.88$ & $2.89 \pm 0.18$ & $1.26 \pm 0.08$ & $40.91 \pm 2.07$ & $3.45 \pm 0.77$ \\
\hline 12 & $4962 \pm 2.26$ & $0.02 \pm 0.00$ & $0.04 \pm 0.00$ & $2.86 \pm 0.45$ & $10.88 \pm 0.34$ & $2.91 \pm 0.51$ & $2.33 \pm 0.29$ & $26.30 \pm 1.90$ & $4.29 \pm 0.37$ \\
\hline 15 & $36.98 \pm 1.35$ & $0.01 \pm 0.01$ & $0.10 \pm 0.02$ & $3.38 \pm 0.81$ & $10.40 \pm 1.62$ & $1.31 \pm 0.57$ & $0.81 \pm 0.17$ & $16.58 \pm 0.79$ & $4.39 \pm 0.76$ \\
\hline 18 & $29.91 \pm 2.50$ & $0.04 \pm 0.00$ & $0.02 \pm 0.00$ & $3.23 \pm 0.82$ & $12.58 \pm 0.81$ & $0.96 \pm 0.27$ & $0.53 \pm 0.09$ & $8.31 \pm 1.39$ & $4.24 \pm 0.85$ \\
\hline 21 & $26.50 \pm 2.55$ & $0.03 \pm 0.01$ & $0.07 \pm 0.01$ & $3.59 \pm 0.32$ & $12.71 \pm 1.50$ & $0.47 \pm 0.14$ & $0.95 \pm 0.19$ & $3.73 \pm 0.41$ & $4.95 \pm 0.81$ \\
\hline 24 & $29.45 \pm 0.63$ & $0.04 \pm 0.00$ & $0.09 \pm 0.01$ & $3.94 \pm 0.05$ & $15.25 \pm 1.26$ & $0.57 \pm 0.09$ & $0.86 \pm 0.13$ & $3.68 \pm 0.38$ & $5.02 \pm 0.88$ \\
\hline 26 & $29.30 \pm 2.10$ & $0.03 \pm 0.00$ & $0.07 \pm 0.01$ & $3.97 \pm 0.55$ & $15.56 \pm 1.04$ & $0.64 \pm 0.26$ & $1.08 \pm 0.21$ & $2.94 \pm 0.66$ & $5.01 \pm 0.74$ \\
\hline 30 & $28.70 \pm 0.80$ & $0.03 \pm 0.00$ & $0.07 \pm 0.01$ & $3.89 \pm 0.35$ & $15.16 \pm 0.80$ & $0.61 \pm 0.21$ & $1.05 \pm 0.18$ & $2.92 \pm 0.43$ & $4.97 \pm 0.12$ \\
\hline
\end{tabular}

${ }^{a}$ Expressed as a percentage of soluble sugar on dry matter. Results are shown as means of triplicate analysis \pm Standard Deviation. UA = uronic acid.

The highest concentration of soluble sugars was reached at $t=9$ (Figure 1) when the Glc concentration detected was $40.91 \%$, followed by $9.15 \%$ Xyl, $3.45 \%$ UA, $2.89 \%$ Man, $2.22 \%$ Ara and $1.26 \%$ Gal. The soluble sugar increase was the result of the insoluble sugar percentage decreasing, as can be observed in Figure 1. In fact, at that stage, the total insoluble sugar decreased from $26.33 \%$ down to $16.04 \%$. This decrease was mainly due to the same monosaccharides increasing in the soluble fraction, as described above (Table 2).

At $t=18$, the substrate utilization reached a plateau; in fact, both the insoluble and the soluble sugar compositions were stable (Figure 1). The main insoluble sugars that could be detected during the last steps of the fermentation process were Xyl, Glu, Ara and UA; whereas Xyl, Ara, Glu and UA could be detected in the soluble fraction.

While the hexoses were used by S. cerevisiae for growth and ethanol production, this yeast species was unable to use the pentoses $[23,25]$. This behavior explains the progressive concentration increase of xylose and arabinose throughout the fermentation process [47].

The decrease in fiber, of course, was due to the enzymatic saccharification of pineapple cell walls. The pentose increase, due to hemicellulose hydrolysis, was caused mostly by Depol ${ }^{\mathrm{TM}} 740 \mathrm{~L}$ [48]. At the same time, Depol's $740 \mathrm{~L}$ activity probably enhanced the Accellerase ${ }^{\circledR} 1500$ activity, considering the presence of ferulic acid, esterified to glucuronoarabinoxylans, in pineapple cell walls [49].

At the end of fermentation, the total insoluble sugars percentage, calculated on dry matter, dropped down to $9.36 \%$; whereas, the total soluble sugars percentage, calculated on dry matter base, decreased from $32.12 \%$ to $28.70 \%$. This value was observed mainly due to the percentage of the unused Xyl remaining in the substrate, which increased from $0.03 \%$ up to $15.16 \%$ during fermentation. On the contrary, the soluble Glc percentage dropped from $26.63 \%$ down to $2.92 \%$.

\subsection{Ethanol and Glycerol Production}

Ethanol production, as well as glycerol production (Figure 1), started at $t=9$, reaching a concentration of $3.45 \%$ and $0.68 \%$, respectively, at $t=15$. While glycerol concentration was not followed by a further increase, ethanol production went up until $t=24$, reaching the highest concentration recorded in this process at $3.9 \%(30.77 \mathrm{~g} / \mathrm{L})$. This represents $85 \%$ of the theoretical yield (TY), calculated as the maximum ethanol yield in relation to dry matter loss $(0.511 \mathrm{~g}$ alcohol per $1.0 \mathrm{~g}$ dry matter). In comparison with previous studies, where the fermentation substrate was not supplemented with a nitrogen source, vitamins and salts [18,50-52], the highest ethanol production ranged from around $6 \mathrm{~g} / \mathrm{L}$ to $10 \mathrm{~g} / \mathrm{L}$, reached between 24 and $72 \mathrm{~h}$. Whereas, in this study, the ethanol production at the end of the SSF process was higher and it was reached within $24 \mathrm{~h}$. This increase in ethanol production could be ascribable to the nutrient supplementation, which enhanced the ethanol production by S. cerevisiae, according to Tropea et al. [23]. The last fermentation phase was characterized by no further ethanol production.

Figure 1 reports the glycerol production during the fermentation time. Glycerol is the main by-product of alcoholic fermentation [53,54] and its synthesis represents an undesirable loss of carbon source, if the aim is to maximize ethanol production. Previous 
studies reported a glycerol percentage of around 1\% [55]. The lower percentage recorded in this study could be ascribable to the addition of salts and vitamin during the fermentation process, as they could promote the NADH re-oxidation by supporting different cellular metabolisms [56-59], resulting in a higher sugar availability for ethanol production.

\section{Conclusions}

The amount of cell wall sugars detected in pineapple waste after enzymatic hydrolysis makes this substrate an interesting resource for bioethanol production. The TY, calculated on dry matter loss, was $85 \%$, making pineapple waste an excellent raw material for ethanol production by S. cerevisiae ATTC 4126. The enzymatic release of xylose and arabinose, sugars not fermented by wild Saccharomyces spp., suggest the use of mixed cultures and/or recombinant yeasts, or to the development of robust strains that could ferment hexoses and pentoses simultaneously, with high ethanol production. This would lead to the improvement of the final ethanol concentration and productivity, since, after fermentation, an amount of pentoses was left unutilized in the medium. A further TY improvement could be finally achieved by carrying out further tests with a strict $\mathrm{pH}$ control during the process, because this could improve the dry matter utilization and, consequently, also the ethanol production. This study pointed out the possibility of using the supplemented pineapple waste cell wall sugar as a fermentation medium for producing second-generation bioethanol, representing the partial valorization of this food industry residue. However, an integrated approach requires producing more value-added products. In this case, the resulting fermentation substrate was enriched in SCP, and was consequently suitable as animal feed, thus replacing expensive conventional sources of protein, like fishmeal and soymeal, and preventing the production of further waste by the end of the fermentation process.

Author Contributions: Conceptualization, F.S., A.F. and A.T.; methodology, F.S., A.F. and A.T.; validation, F.S., A.F. and A.T.; formal analysis, F.S., A.F. and A.T.; investigation, F.S., A.F. and A.T.; data curation, F.S., A.F. and A.T; writing-original draft preparation, F.S., A.F. and A.T.; writingreview and editing, F.S., A.F. and A.T.; supervision, A.T. All authors have read and agreed to the published version of the manuscript.

Funding: This research received no external funding.

Institutional Review Board Statement: Not applicable.

Informed Consent Statement: Not applicable.

Data Availability Statement: Not applicable.

Conflicts of Interest: The authors declare no conflict of interest.

\section{References}

1. Ferracane, A.; Tropea, A.; Salafia, F. Production and maturation of soaps with non-edible fermented olive oil and comparison with classic olive oil soaps. Fermentation 2021, 7, 245. [CrossRef]

2. Goula, A.M.; Lazarides, H.N. Integrated processes can turn industrial foodwaste into valuable food by-products and/or ingredients: The cases of olive milland pomegranate wastes. J. Food Eng. 2015, 167, 45-50. [CrossRef]

3. Campos, D.A.; Gómez-García, R.; Vilas-Boas, A.A.; Madureira, A.R.; Pintado, M.M. Management of fruit industrial by-productsA case study on circular economy approach. Molecules 2020, 25, 320. [CrossRef] [PubMed]

4. Tropea, A.; Potortì, A.G.; Lo Turco, V.; Russo, E.; Vadalà, R.; Rand, R.; Di Bella, G. Aquafeed production from fermented fish waste and lemon peel. Fermentation 2021, 7, 272. [CrossRef]

5. Roda, A.; de Faveri, D.M.; Giacosa, S.; Dordori, R.; Lambri, M. Effect of pretreatments on the saccharification of pineapple waste as a potential source for vinegar production. J. Clean. Prod. 2016, 112, 4477-4484. [CrossRef]

6. Lo Turco, V.; Potortì, A.G.; Tropea, A.; Dugo, G.; Di Bella, G. Element analysis of dried figs (Ficus carica L.) from the Mediterranean areas. J. Food Compos. Anal. 2020, 90, 103503. [CrossRef]

7. Jarunglumlert, T.; Bampenrat, A.; Sukkathanyawat, H.; Prommuak, C. Enhanced energy recovery from food waste by coproduction 2 of bioethanol and biomethane process. Fermentation 2021, 7, 265. [CrossRef]

8. Pandit, S.; Savla, N.; Sonawane, J.M.; Sani, A.M.; Gupta, P.K.; Mathuriya, A.S.; Rai, A.K.; Jadhav, D.A.; Jung, S.P.; Prasad, R. Agricultural waste and wastewater as feedstock for bioelectricity generation using microbial fuel cells: Recent advances. Fermentation 2021, 7, 169. [CrossRef] 
9. Abdullah, M.B.; Mat, H. Characterisation of solid and liquid pineapple waste. Reaktor 2008, 12, 48-52. [CrossRef]

10. Busairi, M.A. Conversion of pineapple juice waste into lactic acid in batch and fed-Batch fermentation systems. Reaktor 2008, 12 , 98-101. [CrossRef]

11. Jamal, P.; Fahrurrazi, T.M.; Zahangir, A.M. Optimization of media composition for the production of bioprotein from pineapple skins by liquid-state bioconversion. J. Appl. Sci. 2009, 9, 3104-3109. [CrossRef]

12. Raji, Y.O.; Jibril, M.; Misau, I.M.; Danjuma, B.Y. Production of vinegar from pineapple peel. Int. J. Adv. Sci. Res. Technol. 2012, 3, 656-666.

13. Imandi, S.B.; Bandaru, V.V.R.; Somalanka, S.R.; Bandaru, S.R.; Garapati, H.R. Application of statistical experimental designs for the optimization of medium constituents for the production of citric acid from pineapple waste. Bioresour. Technol. 2008, 99, 4445-4450. [CrossRef] [PubMed]

14. Gil, L.S.; Maupoey, P.F. An integrated approach for pineapple waste valorisation. Bioethanol production and bromelain extraction from pineapple residues. J. Clean. Prod. 2018, 172, 1224-1231. [CrossRef]

15. Beigbeder, J.-B.; de Medeiros Dantas, J.M.; Lavoie, J.-M. Optimization of yeast, sugar and nutrient concentrations for high ethanol production rate using industrial sugar beet molasses and response surface methodology. Fermentation 2021, 7, 86. [CrossRef]

16. Asimakopoulou, G.; Karnaouri, A.; Staikos, S.; Stefanidis, S.D.; Kalogiannis, K.G.; Lappas, A.A.; Topakas, E. Production of omega-3 fatty acids from the microalga Crypthecodinium cohnii by utilizing both pentose and hexose sugars from agricultural residues. Fermentation 2021, 7, 219. [CrossRef]

17. Sun, Y.; Cheng, J. Hydrolysis of lignocellulosic materials for ethanol production: A review. Bioresour. Technol. 2002, 83, 1-11. [CrossRef]

18. Himmel, M.E.; Ding, S.Y.; Johnson, D.K.; Adney, W.S.; Nimlos, M.R.; Brady, J.W.; Foust, T.D. Biomass recalcitrance: Engineering plants and enzymes for biofuels production. Science 2007, 315, 804-807. [CrossRef]

19. Galbe, M.; Zacchi, G. Pretreatment of lignocellulosic materials for efficient bioethanol production. Adv. Biochem. Eng. Biotechnol. 2007, 108, 41-65. [CrossRef]

20. Prasad, R.K.; Chatterjee, S.; Mazumder, P.B.; Gupta, S.K.; Sharma, S.; Vairale, M.G.; Datta, S.; Dwivedi, S.K.; Gupta, D.K. Bioethanol production from waste lignocelluloses: A review on microbial degradation potential. Chemosphere 2019, 231, 588-606. [CrossRef]

21. Pereira, F.B.; Guimaraes, P.M.; Teixeira, J.A.; Domingues, L. Robust industrial Saccharomyces cerevisiae strains for very high gravity bio-ethanol fermentations. J. Biosci. Bioeng. 2011, 112, 130-136. [CrossRef] [PubMed]

22. Mussatto, S.I.; Dragone, G.; Guimarães, P.M.R.; Silva, J.P.A.; Carneiro, L.M.; Roberto, I.C.; Vicente, A.; Domingue, L.; Teixeira, J.A. Technological trends, global market, and challenges of bio-ethanol production. Biotechnol. Adv. 2010, 28, 817-830. [CrossRef] [PubMed]

23. Tropea, A.; Wilson, D.; Cicero, N.; Potortì, A.G.; La Torre, G.L.; Dugo, G.; Richardson, D.; Waldron, K.W. Development of minimal fermentation media supplementation for ethanol production using two Saccharomyces cerevisiae strains. Nat. Prod. Res. 2016, 30, 1009-1016. [CrossRef] [PubMed]

24. Dahnum, D.; Tasum, S.O.; Triwahyuni, E.; Nurdin, M.; Abimanyu, H. Comparison of SHF and SSF processes using enzyme and dry yeast for optimization of bioethanol production from empty fruit bunch. Energy Procedia 2015, 68, 107-116. [CrossRef]

25. Tropea, A.; Wilson, D.; Lo Curto, R.B.; Dugo, G.; Saugman, P.; Troy-Davies, P.; Waldron, K.W. Simultaneous saccharification and fermentation of lignocellulosic waste material for second generation ethanol production. J. Biol. Res. 2015, 88, 142-143.

26. Chintagunta, A.D.; Ray, S.; Banerjee, R. An integrated bioprocess for bioethanol and biomanure production from pineapple leaf waste. J. Clean. Prod. 2017, 165, 1508-1516. [CrossRef]

27. Tengborg, C.; Galbe, M.; Zacchi, G. Reduced inhibition of enzymatic hydrolysis of steam pretreated softwood. Enzym. Microb. Technol. 2001, 28, 835-844. [CrossRef]

28. Tropea, A.; Ferracane, A.; Albergamo, A.; Potortì, A.G.; Lo Turco, V.; Di Bella, G. Single cell protein production through multi food-waste substrate fermentation. Fermentation 2022, 8, 91. [CrossRef]

29. AOAC. Official Methods of Analysis, 18th ed.; Association of Official Analytical Chemists Arlington: Gaithersburg, MD, USA, 2012.

30. Carrier, M.; Loppinet Serani, A.; Denux, D.; Lasnier, J.; Ham Pichavant, F.; Cansell, F.; Aymonier, C. Thermogravimetric analysis as a new method to determine the lignocellulosic composition of biomass. Biomass Bioenergy 2011, 35, 298-307. [CrossRef]

31. Waldron, K.W.; Selvendran, R.R. Composition of the cell walls of different asparagus (Asparagus officinalis) tissues. Physiol. Plant. 1990, 80, 568-575. [CrossRef]

32. Mandalari, G.; Faulds, C.B.; Sancho, A.I.; Saija, A.; Bisignano, G.; Lo Curto, R.; Waldron, K.W. Fractionation and characterisation of arabinoxylans from brewers spent grain and wheat bran. J. Cereal Sci. 2005, 42, 205-212. [CrossRef]

33. Blakeney, A.B.; Harris, P.J.; Henry, R.J.; Stone, B.A. A simple and rapid preparation of alditol acetates for monosaccharide analysis. Carbohydr. Res. 1983, 113, 291-299. [CrossRef]

34. Bastos, R.; Coelho, E.; Coimbra, M.A. Modifications of Saccharomyces pastorianus cell wall polysaccharides with brewing process. Carbohydr. Polym. 2015, 124, 322-330. [CrossRef] [PubMed]

35. Blumenkrantz, N.; Asboe-Hansen, G. New method for quantitative determination of uronic acids. Anal. Biochem. 1973, 54, 484-489. [CrossRef]

36. Rae, A.L.; Harris, P.J.; Bacic, A.; Clarke, A.E. Composition of the cell walls of Nicotiana alata Link et Otto pollen tubes. Planta 1985, 166, 128-133. [CrossRef] 
37. Eliston, A.; Collins, A.; Wilson, D.; Robert, N.; Waldron, K.W. High concentrations of cellulosic ethanol achieved by fed batch semi simultaneous saccharification and fermentation of waste-paper. Bioresour. Technol. 2013, 134, 117-126. [CrossRef]

38. Aruna, T.E.; Aworh, O.C.; Raji, A.O.; Olagunju, A.I. Protein enrichment of yam peels by fermentation with Saccharomyces cerevisiae (BY4743). Ann. Agric. Sci. 2017, 62, 33-37. [CrossRef]

39. Aruna, T.E. Production of value-added product from pineapple peels using solid state fermentation. Innov. Food Sci. Emerg. Technol. 2019, 57, 102193. [CrossRef]

40. Alexandre, H.; Guilloux-Benatier, M. Yeast autolysis in sparkling wine. Aust. J. Grape Wine Res. 2006, 12, 119-127. [CrossRef]

41. Schiavone, M.; Sieczkowski, N.; Castex, M.; Dague, E.; François, J.M. Effects of the strain background and autolysis process on the composition and biophysical properties of the cell wall from two different industrial yeasts. FEMS Yeast Res. 2015, 15, fou012. [CrossRef]

42. Filippov, M.P.; Shkolenko, G.A.; Kohn, R. Determination of the esterification degree of the pectin of different origin and composition by the method of infrared spectroscopy. Chem. Zvesti. 1978, 32, 218-222.

43. Zaldivar, J.; Nielsen, J.; Olsson, L. Fuel ethanol production from lignocellulose: A challenge for metabolic engineering and process integration. Appl. Microbiol. Biotechnol. 2001, 56, 17-34. [CrossRef] [PubMed]

44. Forssell, P.; Kontkanen, H.; Schols, H.A.; Hinz, S.; Eijsink, V.G.H.; Treimo, J.; Robertson, J.A.; Waldron, K.W.; Faulds, C.B.; Buchert, J. Hydrolysis of brewers' spent grain by carbohydrate degrading enzymes. J. Inst. Brew. 2008, 4, 114-120. [CrossRef]

45. Araya-Cloutier, C.; Rojas-Garbanzo, C.; Velàzquez-Carrillo, C. Effect of initial sugar concentration on the production of L(+) lactic acid by simultaneous enzymatic hydrolysis and fermentation of an agro-industrial waste product of pineapple (Ananas comosus) using Lactobacillus casei subspeies rhamnosus. Int. J. Biotechnol. Wellness Ind. 2012, 1, 91-100. [CrossRef]

46. Huang, Y.L.; Chow, C.J.; Fang, Y.J. Preparation and physicochemical properties of fiber-rich fraction from pineapple peels as a potential ingredient. J. Food Drug Anal. 2011, 19, 318-323. [CrossRef]

47. Van Maris, A.J.A.; Abbott, D.A.; Bellissimi, E.; van den Brink, J.; Kuyper, M.; Luttik, M.A.H.; Wisselink, H.W.; Scheffers, W.A.; van Dijken, J.P.; Pronk, J.T. Alcoholic fermentation of carbon sources in biomass hydrolysates by Saccharomyces cerevisiae: Current status. Antonie Van Leeuwenhoek 2006, 90, 391-418. [CrossRef]

48. Treimo, J.; Westereng, B.; Horn, S.J.; Forssell, P.; Robertson, J.A.; Faulds, C.B.; Waldron, K.W.; Buchert, J.; Eijsink, V.G.H. Enzymatic solubilization of brewers' spent grain by combined action of carbohydrases and peptidases. J. Agric. Food Chem. 2009, 57, 3316-3324. [CrossRef]

49. Smith, B.G.; Harris, P.J. Ferulic acid is esterified to glucuronoarabinoxylans in pineapple cell walls. Phytochemistry 2001, 56, 513-519. [CrossRef]

50. Bhatia, L.; Johri, S. Biovalorization potential of peels of Ananas cosmosus (L.) Merr. for ethanol production by Pichia stipitis NCIM 3498 \& Pachysolen tannophilus MTCC 1077. Indian J. Exp. Biol. 2015, 53, 819-827.

51. Choonut, A.; Saejong, M.; Sangkharak, K. The production of ethanol and hydrogen from pineapple peel by Saccharomyces cerevisiae and Enterobacter aerogenes. Energy Procedia 2014, 52, 242-249. [CrossRef]

52. Casabar, J.T.; Unpaprom, Y.; Ramaraj, R. Fermentation of pineapple fruit peel wastes for bioethanol production. Biomass Convers. Biorefinery 2019, 9, 761-765. [CrossRef]

53. Choi, W.J. Glycerol-based biorefinery for fuels and chemicals. Recent Pat. Biotechnol. 2008, 2, 173-180. [CrossRef] [PubMed]

54. Da Silva, G.P.; Mack, M.; Contiero, J. Glycerol: A promising and abundant carbon source for industrial microbiology. Biotechnol. Adv. 2009, 27, 30-39. [CrossRef] [PubMed]

55. Bai, F.W.; Anderson, W.A.; Moo-Young, M. Ethanol fermentation technologies from sugar and starch feedstocks. Biotechnol. Adv. 2008, 26, 89-105. [CrossRef]

56. Nissen, T.L.; Kielland-Brandt, M.C.; Nielsen, J.; Villadsen, J. Optimization of ethanol production in Saccharomyces cerevisiae by metabolic engineering of the ammonium assimilation. Metab. Eng. 2000, 2, 69-77. [CrossRef]

57. Nissen, T.L.; Hamann, C.W.; Kielland-Brandt, M.C.; Nielsen, J.; Villadsen, J. Anaerobic and aerobic batch cultivations of Saccharomyces cerevisiae mutants impaired in glycerol synthesis. Yeast 2000, 16, 463-474. [CrossRef]

58. Hou, J.; Lages, N.F.; Oldiges, M.; Vemuri, G.N. Metabolic impact of redox cofactor perturbations in Saccharomyces cerevisiae. Metab. Eng. 2009, 11, 253-261. [CrossRef]

59. Guadalupe, M.V.; Almering, M.J.; van Maris, A.J.; Pronk, J.T. Elimination of glycerol production in anaerobic culture sofa Saccharomyces cerevisiae strain engineered to use acetic acid as an electron acceptor. Appl. Environ. Microbiol. 2010, 76, 190-195. [CrossRef] 